\title{
The Nutritional Properties of Killed Bacterium coli
}

\author{
BY R. S. ROBERTS \\ The Evans Biological Institute, Runcorn, Cheshire \\ (Received 26 April 1954)
}

A previous investigation had shown that the protein and polysaccharide components of enteric bacteria can be separated by heating the cells in a watery suspension at $80^{\circ}$ for $\mathrm{I} h$ (Roberts, I949). In continuation of this work the protein of Bacterium coli was fed to rats and guinea-pigs and it was found that if the diet satisfied the peculiar vitamin requirements of the experimental animals, as, for example, the need of vitamin $\mathrm{C}$ in the diet of guinea-pigs, the animals thrived. It was then found that rats receiving both components, i.e. whole cells, grew at the same rate as rats receiving only the bacterial-protein component. Thus, whereas it might have been accepted as highly probable on theoretical grounds that the protein component of an enteric bacterium was edible, this last observation suggested the wider possibility that the whole organism might be edible. As Bact. coli can grow profusely in protein- and vitaminfree media it seemed to be an ideal food organism. A systematic study of the nutritional properties of killed Bact. coli suspensions was therefore undertaken.

The plan was first to demonstrate that Bact. coli suspensions could be substituted for animal protein, secondly to ascertain broadly the dietary factors that were complementary to Bact. coli and thirdly to demonstrate its use in a diet for chicks. The work on chicks was undertaken to test the merits of the material in an exacting species, rather than to formulate a practical chick ration. It proved that a suspension of Bact. coli organisms killed by heat could replace substantially the protein supplements customarily added to cereal diets for chicks.

\section{EXPERIMENTAL AND RESULTS}

\section{Materials}

Strain of Bact. coli. The strain was that mainly used in a previous investigation (Roberts, 1949) and possessed the classical characters of Bact. coli. It had been isolated from a lymph node from a calf that died of white scour.

Culture medium. This consisted of $0.5 \%$ ammonium sulphate, $2.0 \%$ glucose, $0.2 \%$ potassium dihydrogen phosphate, $0.05 \%$ magnesium sulphate and $0.02 \%$ sodium citrate, in tap water.

Bact. coli cultures. During most of the work the cultures used had a viable count of $2 \times 10^{10}$ and contained $4 \mathrm{~g}$ protein $/ \mathrm{l}$.

Bact. coli suspension. The organisms were collected alive by centrifuging, resuspended in physiological salt solution and killed by heating at $80^{\circ}$ for $\mathrm{I}$ h. This suspension was then tested to ensure its sterility and assayed for protein $(\mathrm{N} \times 6.25)$. For use in feeding experiments it was diluted later to a protein content per $100 \mathrm{ml}$. equal to 
the amount of bacterial protein to be added to roo $\mathrm{g}$ dry food. The food as given to the animals was thus a mixture of equal parts of dry food in $\mathrm{g}$ and Bact. coli suspension in $\mathrm{ml}$.

This suspension was measured in terms of its protein content; its other ingredients were ignored. It consisted in effect of a suspension of killed organisms and insoluble salts, mainly calcium, in a solution of bacterial polysaccharide with traces of the solutes from the culture fluid (Roberts, 1949). The solids in a typical sample of the preparation consisted of $64 \%$ organic matter and $36 \%$ ash. The organic matter contained $8 \mathrm{I} \%$ protein, $0.73 \%$ carbohydrate (as starch) and $0.29 \%$ fat.

Fish meal. This contained $75 \%$ protein.

Fish solubles. The solids content was $44 \%$, and $75 \%$ of the dry matter was protein.

Rats. Part of the work was carried out with rats from the Ministry of Supply Laboratories, Porton, and part with rats bred from the same stock in a closed colony at the laboratory. The experimental groups were made up by matching each rat in one group with a rat of the same sex and weight in other groups. The groups consisted of all male rats, or approximately half male and half female. The two sexes were in separate cages.

Chicks. These were cockerels purchased as day-olds from a commercial hatchery. Owing to the seasonal changes from breed to breed at the hatchery it was not possible to use the same breed throughout the work. Experimental groups were at first formed by randomizing techniques but later it was found preferable to match each chick in one group with a chick of the same weight in the other group. Each chick was identified. The brooders were in a thermostatically controlled building and were designed to give two groups of chicks equal access to the same source of heat. The floors were of small-mesh wire.

\section{Methods}

Cultivation of Bact. coli. The technique used was either an adaptation to a larger vessel of the aeration technique described earlier (Roberts 1950) or a vortex-stirring technique (Chain, Paladino, Callow, Ugolini \& van der Sluis, I952). The $\mathrm{pH}$ was controlled by adding lime during growth.

Feeding. Rats and chicks were fed twice daily with amounts that ensured that some food remained at the time of the next feed. The food left was discarded. The feeds were made up by mixing the basal diet and the Bact. coli suspension into a wet mash; corresponding amounts of tap water were used to mix control diets.

\section{Confirmation of the need to remove culture fluid}

While the work described later in this report was in progress, some collateral work was done to determine whether the suspension of Bact. coli being used was in fact the miost suitable preparation. The following is a summary of other preparations considered or investigated, and of the evidence against them. ( $\mathrm{I}$ ) Living culture. In some early experiments bacterial suspensions containing a small number of living organisms were fed, in error, to some chicks and rats. The animals ceased to thrive, some died, and rich cultures of Bact. coli were obtained from their heart blood. It appeared 
therefore that with this strain of Bact. coli there was little prospect of the successful use of living culture (cf. Anderson, Slinger \& Pepper (1953) who used living cultures). (2) Evaporated whole culture. Evaporation at $40-50^{\circ}$ was considered as an alternative to centrifuging as a means of concentrating the culture. The first preparations tested caused rapid loss of weight and deaths when added to the diet of rats. Further experiments were made and it was found that if the cultures were grown in a medium balanced so that its constituents were exhausted when growth finished, the evaporated preparations were tolerated but had no beneficial effects, e.g. a group of sixteen chicks fed on a basal ration and this preparation for 3 weeks weighed on an average $153 \mathrm{~g}$. The average weight of a similar group, receiving the same amount of fish-meal protein, was I64 g. (3) Killed whole culture. The addition of an equal weight of liquid Bact. coli culture to a basal diet for rats had an adverse effect on weight gains, even though the amount added represented less bacterial protein than the lowest amounts that were effective in the form of saline suspensions. These results all compared unfavourably with those being obtained with saline suspensions of cells, and they suggested that the culture fluid was toxic. It is not desired to infer that no preparation containing culture fluid can be used as a food supplement, but the evidence against it was considered to be enough to warrant a conclusion that it was preferable to use material containing as little culture fluid as possible.

\section{Growth response in young rats}

The purpose of these experiments was to ascertain whether Bact. coli protein could be substituted for animal protein in the diet of young rats. The design of the experiments was adapted from the work of Woodman \& Evans (I95I) on protein supplement in pig food. Briefly it consisted of observing weight gains of young rats over a period of 3 or 4 weeks and comparing the response to Bact. coli protein with the response to fish meal. The basal diet consisted of 2 parts barley meal and I part fine wheat bran with $0.5 \%$ cod-liver oil and $2.5 \%$ mineral mixture. This diet contained I $1.5 \%$ protein. The addition of $7 \%$ fish meal was equivalent to an addition of $5.25 \%$ protein and was excessive in that it did not lead to greater weight gains than an addition of $4 \%$. Food and water were given ad lib. The results are shown in Table $\mathrm{I}$.

It became evident early in the course of these experiments that the effect of using Bact. coli as a protein for young rats was similar to that of using fish meal. Thus, in Exp. 3 groups of rats receiving a supplement of $5.25 \%$ Bact. coli protein gained weight at the same rate as rats receiving a supplement of $5.25 \%$ fish-meal protein. When the effect of a supplement of $0.7 \%$ Bact. coli protein was compared with that of a fishmeal supplement of $7 \%$ (Exp. I) the weight gain of the Bact. coli group was greater than that of the basal-mash group, and less than that of the fish-meal group. Assuming that the fish-meal diet was an adequate one, then the optimum level of Bact. coli protein for this basal diet was between 0.7 and $5.25 \%$. In Exp. 2, levels of Bact. coli protein increasing in series by $50 \%$, from $\mathrm{I} \cdot 56$ to $5.25 \%$ were added to the basal diet. The weight gains of the four groups did not differ significantly. It would appear therefore that about $\mathrm{r} \cdot 6 \%$ Bact. coli protein might be a sufficient supplement for this basal diet. Certain discrepancies in the appearance and weights of the rats, however, 
raised doubts about it. Thus, it was observed that in groups receiving the smaller supplements of Bact. coli protein some of the rats lacked vitality and grew too slowly in the ist week of the experiment. The possibility was therefore considered that the use of some substance of animal origin with the Bact. coli protein might be advantageous. In Exp. 3 the effect of a supplement of Bact. coli protein alone was compared with that of Bact. coli protein with fish solubles; this experiment failed to demonstrate

Table $\mathrm{x}$. Growth responses in young rats to a dietary supplement of killed Bact. coli, fish meal or liver to a basal diet of barley and bran

\begin{tabular}{|c|c|c|c|c|c|c|c|c|c|}
\hline \multirow{2}{*}{$\begin{array}{c}\text { Exp. } \\
\text { no. }\end{array}$} & \multirow{2}{*}{\multicolumn{2}{|c|}{$\begin{array}{l}\text { Protein added to } \\
\text { basal diet } \\
(\%)\end{array}$}} & \multirow{2}{*}{$\begin{array}{c}\text { Other } \\
\text { supplements }\end{array}$} & \multirow{2}{*}{$\begin{array}{l}\text { No. and } \\
\text { sex of } \\
\text { rats }\end{array}$} & \multirow{2}{*}{$\begin{array}{l}\text { Initial } \\
\text { mean } \\
\text { weight } \\
\text { (g) }\end{array}$} & \multicolumn{3}{|c|}{$\begin{array}{l}\text { Mean weight gains } \\
\text { (g) in week }\end{array}$} & \multirow{2}{*}{$\begin{array}{c}\text { Total mean } \\
\text { weight gain } \\
\text { in } 3 \text { weeks (g) } \\
\text { with its } \\
\text { standard error }\end{array}$} \\
\hline & & & & & & $\mathbf{I}$ & 2 & 3 & \\
\hline I & $\begin{array}{l}\text { None } \\
\text { Fish meal } \\
\text { Bact. coli }\end{array}$ & $\begin{array}{l}5.25 \\
0.7\end{array}$ & $\begin{array}{l}\text { None } \\
\text { None } \\
\text { None }\end{array}$ & $\begin{array}{l}10 \sigma+q \\
10 j+q \\
100+q\end{array}$ & $\begin{array}{l}86 \\
85 \\
85\end{array}$ & $\begin{array}{l}16 \\
33 \\
23\end{array}$ & $\begin{array}{l}12 \\
22 \\
18\end{array}$ & $\begin{array}{l}10 \\
23 \\
19\end{array}$ & $\begin{array}{l}3^{8} \pm 3^{\cdot} 4 \\
78 \pm 5 \cdot 9 \\
60 \pm 4^{\cdot 8}\end{array}$ \\
\hline 2 & Bact. coli. & $\begin{array}{l}5 \cdot 25 \\
3 \cdot 5 \\
2 \cdot 33 \\
1 \cdot 56\end{array}$ & $\begin{array}{l}\text { None } \\
\text { None } \\
\text { None } \\
\text { None }\end{array}$ & 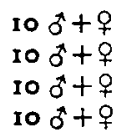 & $\begin{array}{l}79 \\
79 \\
79 \\
79\end{array}$ & $\begin{array}{l}27 \\
26 \\
22 \\
18\end{array}$ & $\begin{array}{l}16 \\
20 \\
25 \\
23\end{array}$ & $\begin{array}{l}24 \\
27 \\
23 \\
25\end{array}$ & $\begin{array}{l}67 \pm 5 \cdot 9 \\
73 \pm 7 \cdot 3 \\
70 \pm 5 \cdot 9 \\
66 \pm 4 \cdot 4\end{array}$ \\
\hline 3 & $\begin{array}{l}\text { Fish meal } \\
\text { Bact. coli }\end{array}$ & $\begin{array}{l}5 \cdot 25 \\
5 \cdot 25 \\
5 \cdot 25\end{array}$ & $\begin{array}{l}\text { None } \\
\text { None } \\
\text { F.S. }\end{array}$ & $\begin{array}{l}10 a+q \\
10 a+q \\
10 a+q\end{array}$ & $\begin{array}{l}67 \\
66 \\
66\end{array}$ & $\begin{array}{l}26 \\
19 \\
20\end{array}$ & $\begin{array}{l}26 \\
28 \\
28\end{array}$ & $\begin{array}{l}28 \\
30 \\
32\end{array}$ & $\begin{array}{l}80 \pm 6 \cdot 4 \\
77 \pm 6 \cdot 7 \\
80 \pm 7 \cdot 6\end{array}$ \\
\hline 4 & $\begin{array}{l}\text { Fish meal } \\
\text { Bact. coli }\end{array}$ & $\begin{array}{l}5 \cdot 25 \\
5 \cdot 25 \\
5 \cdot 25\end{array}$ & $\begin{array}{l}\text { None } \\
\text { None } \\
\text { F.S. }\end{array}$ & $\begin{array}{l}8 \sigma+q \\
8 \sigma+q \\
8 \sigma+q\end{array}$ & $\begin{array}{l}53 \\
53 \\
53\end{array}$ & $\begin{array}{l}25 \\
25 \\
27\end{array}$ & $\begin{array}{l}32 \\
29 \\
31\end{array}$ & $\begin{array}{l}28 \\
21 \\
26\end{array}$ & $\begin{array}{l}85 \pm 5 \cdot 6 \\
75 \pm 4 \cdot 1 \\
84 \pm 3 \cdot 7\end{array}$ \\
\hline 5 & $\begin{array}{l}\text { None } \\
\text { Fish meal } \\
\text { Bact. coli }\end{array}$ & $\begin{array}{l} \\
5 \cdot 25 \\
5 \cdot 25 \\
5 \cdot 25\end{array}$ & $\begin{array}{l}\text { F.S. } \\
\text { F.S. } \\
\text { F.S. } \\
0.5 \% \text { liver }\end{array}$ & $\begin{array}{l}80 \\
80 \\
70 \\
70\end{array}$ & $\begin{array}{l}63 \\
63 \\
65 \\
64\end{array}$ & $\begin{array}{l}20 \\
32 \\
27 \\
27\end{array}$ & $\begin{array}{l}19 \\
35 \\
30 \\
34\end{array}$ & $\begin{array}{l}16 \\
23 \\
33 \\
22\end{array}$ & $\begin{array}{l}55 \pm 2 \cdot 7 \\
90 \pm 3 \cdot 8 \\
90 \pm 7 \cdot 0 \\
83 \pm 8 \cdot 3\end{array}$ \\
\hline 6 & $\begin{array}{l}\text { Fish meal } \\
\text { Bact. coli }\end{array}$ & $\begin{array}{l}5 \cdot 25 \\
5 \cdot 25\end{array}$ & $\begin{array}{l}\text { F.S. } \\
\text { F.S. }\end{array}$ & $\begin{array}{l}100+q \\
110+q\end{array}$ & $\begin{array}{l}40 \\
40\end{array}$ & $\begin{array}{l}11 \\
18\end{array}$ & $\begin{array}{l}23 \\
18\end{array}$ & $\begin{array}{l}33 \\
26\end{array}$ & $\begin{array}{l}67 \pm 4 \cdot 0 \\
62 \pm 5 \cdot 1\end{array}$ \\
\hline 7 & $\begin{array}{l}\text { Bact. coli } \\
\text { Diet } 4 \mathrm{r}^{*}\end{array}$ & $\begin{array}{l}5 \cdot 25 \\
3 \cdot 5 \\
2 \cdot 33 \\
r \cdot 56\end{array}$ & $\begin{array}{l}\text { F.S. } \\
\text { F.S. } \\
\text { F.S. } \\
\text { F.S. } \\
\text { - }\end{array}$ & $\begin{array}{l}90^{*} \\
100^{4} \\
100^{\circ} \\
100^{\circ} \\
140^{\circ}\end{array}$ & $\begin{array}{l}51 \\
49 \\
49 \\
49 \\
54\end{array}$ & $\begin{array}{l}26 \\
22 \\
20 \\
20 \\
25\end{array}$ & $\begin{array}{l}31 \\
32 \\
38 \\
28 \\
29\end{array}$ & $\begin{array}{l}30 \\
26 \\
20 \\
30 \\
24\end{array}$ & $\begin{array}{l}87 \pm 4 \cdot 0 \\
80 \pm 40 \\
78 \pm 2 \cdot 6 \\
78 \pm 3 \cdot 4 \\
78 \pm 4 \cdot 5\end{array}$ \\
\hline 8 & Bact. coli & $\begin{array}{l}2 \cdot 0 \\
1 \cdot 0 \\
0\end{array}$ & $\begin{array}{l}\text { F.S. } \\
\text { F.S. } \\
\text { F.S. }\end{array}$ & $\begin{array}{l}10 \pi+9 \\
100+q \\
100+9\end{array}$ & $\begin{array}{l}55 \\
54 \\
54\end{array}$ & $\begin{array}{l}20 \\
17 \\
16\end{array}$ & $\begin{array}{l}28 \\
28 \\
24\end{array}$ & $\begin{array}{l}23 \\
26 \\
\text { II }\end{array}$ & $\begin{array}{l}71 \pm 3 \cdot 6 \\
71 \pm 3 \cdot 6 \\
51 \pm 5 \cdot 0\end{array}$ \\
\hline
\end{tabular}

F.S. $=\mathbf{I} \%$ fish solubles.

Liver $=$ desiccated proteolysed liver.

- Bruce \& Parkes (1949).

any advantage in the use of fish solubles with the Bact. coli protein. In all the above experiments the rats weighed over $60 \mathrm{~g}$. In Exp. 4 a comparison similar to that in Exp. 3 was made using younger rats, and the weight gain of the group receiving fish solubles was greater than that of the group receiving Bact. coli protein only; the difference was significant however only at a level of 0.1 . The view was taken that a satisfactory answer to the question of whether there was an advantage in supplementing a Bact. coli diet with fish solubles or other substances of animal origin might not be obtained without a fundamental analysis of the growth factors involved, and 
that for the purposes of this investigation it had to be accepted tentatively that it was beneficial to add some such substance.

The result of Exp. 5 supported the general conclusion that Bact. coli protein was qualitatively comparable with fish meal. In one group of rats in this experiment proteolysed liver was used instead of fish solubles and there was little difference in the resulting weight gains. This finding suggested that there was no reason for searching further for a complementary supplement of an animal-protein nature, and fish solubles, being an abundant commodity, were regarded as a part of the basal diet in further work.

The result of Exp. 6 showed that, with fish solubles, Bact. coli protein and fish meal were similar in their effects on the weight gains of very young rats as the difference between the weight gains of the two groups was not significant.

It would have been of interest to determine with moderate precision the optimum quantity of Bact. coli protein supplement for some given cereal diet. It was found, however, that when the amount of supplement was near the lower limits of effectiveness, it was difficult to obtain consistent results. The response at these levels may indeed have been a quantal one, and not capable of measurement by the experimental procedure used. It was shown in Exp. 7 that with fish solubles in the diet the effect on weight gains of young male rats was approximately equal over the range of I. $56-5 \cdot 25 \%$ Bact. coli protein supplement. This rate of weight increase was also the same as that of a control group fed on rat diet $4 \mathrm{I}$ of Bruce $\&$ Parkes (1949). In Exp. 8, the same effect was observed with $I$ as with $2 \%$ Bact. coli protein supplement when male and female rats were used. Inconsistent results were observed with a supplement of $0.5 \%$. It may be concluded from these experiments that with this basal diet, which included I \% fish solubles, the optimum amount of Bact. coli protein was probably not greater than $\mathrm{I} \%$.

\section{Growth response of chicks to cereal and Bact. coli diets}

The purpose of the work described in this section was to determine whether chicks could be reared on a diet consisting essentially of cereals and Bact. coli protein. Some preliminary experiments were carried out to find a satisfactory basal diet. The essential result of these was to show that grass meal was an indispensable constituent of diets containing Bact. coli. The basal diet used consisted of 2 parts barley meal and I part fine wheat bran, $2 \%$ grass meal, $\mathrm{I} \%$ fish solubles, $2.5 \%$ mineral mixture with sufficient $\mathrm{MnSO}_{4}$ to give a concentration of $0.02 \%$ in the diet, and $0.5 \%$ cod-liver oil. Two batches of this mixture were used, one containing $12 \cdot 2 \%$ protein and the other $7 \cdot 7 \%$. No satisfactory explanation of the low protein content of the latter mixture was found; the possibility of accidental omission of the bran and of the inclusion of a low-protein contaminant can be excluded. The amount of cod-liver oil wasincreased to $\mathrm{I} \cdot 0 \%$ in later experiments. The work consisted mainly of a series of simple experiments in which the weight gains of two groups of chicks on two diets were compared.

Two experiments were carried out in which the weight gains of a group of chicks receiving a supplement of $5.25 \%$ Bact. coli protein were compared with those of a group receiving the same amount of fish-meal protein. In both experiments the 
chicks in the fish-meal protein groups failed to thrive and some died. Those in the Bact. coli groups thrived, and all survived. The results of one of these experiments are shown in Table 2. The table also includes, for comparison, a record of the weights of a group of similar chicks from the same stock, reared on standard mash during the succeeding month.

Table 2. Effects of supplements of fish meal and Bact. coli protein to a basal diet of bran, barley and $1 \%$ fish solubles on the weight gains of chicks

\begin{tabular}{|c|c|c|c|c|c|c|c|c|}
\hline \multirow[b]{2}{*}{ Diet } & \multirow[b]{2}{*}{$\begin{array}{l}\text { No. of } \\
\text { chicks }\end{array}$} & \multirow[b]{2}{*}{$\begin{array}{l}\text { No. of } \\
\text { deaths }\end{array}$} & \multicolumn{4}{|c|}{$\begin{array}{l}\text { Mean weight gain (g) } \\
\text { in week }\end{array}$} & \multirow{2}{*}{$\begin{array}{l}\text { Total mean } \\
\text { weight gain (g) } \\
\text { in } 4 \text { weeks } \\
\text { with its } \\
\text { standard error }\end{array}$} & \multirow{2}{*}{$\begin{array}{c}\text { Final } \\
\text { weight } \\
\text { (g) }\end{array}$} \\
\hline & & & 1 & 2 & 3 & & & \\
\hline $\begin{array}{l}\text { Basal with } 5 \cdot 25 \% \text { fish- } \\
\text { meal protein }\end{array}$ & 11 & 3 & 16 & 42 & 78 & 95 & $23 I^{*} \pm 17 \cdot 2$ & 271 \\
\hline $\begin{array}{l}\text { Basal with } 5 \cdot 25 \% \text { Bact. } \\
\text { coli protein }\end{array}$ & 12 & $\circ$ & 28 & 51 & 77 & 120 & $276^{*} \pm 14^{-1}$ & 315 \\
\hline Standard mash & 12 & $\mathbf{I}$ & 27 & 47 & 85 & 127 & $286 \pm I I \cdot 3$ & 322 \\
\hline
\end{tabular}

The results of these experiments suggested that little further was to be gained by endeavouring to compare the effects of Bact. coli protein supplements with those of any one other protein. The experimental design was therefore reviewed and the possibility was investigated of formulating a diet based on Bact. coli protein that would give results comparable to those of a market sample of chick mash sold by a reputable manufacturer. The chick mash selected contained $18.3 \%$ total protein, $7 \frac{1}{2} \%$ fish meal, $2 \frac{1}{2} \%$ liver meal, $1 \frac{1}{4} \%$ dried skim milk, $1 \frac{1}{4} \%$ dried whey, $5 \%$ dried grass and $4 \mathrm{~g}$ riboflavin/ton. A series of experiments was carried out in which the weight gains of chicks receiving the basal diet (12.2\% protein) supplemented with various percentages of Bact. coli protein were compared with those of chicks fed on this chick mash.

The weight gains of the groups receiving the Bact. coli, expressed as a percentage of the weight gain of the group fed on the standard mash, are shown in Table 3. It will be seen that there was a correlation between the amount of Bact. coli given and the weight gains. It seems likely in the light of subsequent experience that in this series of experiments the amount of cod-liver oil used was insufficient, so that at the higher levels of Bact. coli protein supplement the cod-liver oil may have become the limiting factor. This view is based on the results of an experiment in which the weight gains of chicks receiving $1 \%$ of this cod-liver oil were $19 \%$ greater than those of chicks receiving $0.5 \%$.

In a further series of experiments a basal diet of the same ingredients but containing only $7.7 \%$ protein was used. The mean weight gains in 4 weeks of groups of twenty chicks receiving it and a supplement of $5.25 \%$ Bact. coli protein in three experiments were 85,93 and $94 \%$ of the weight gains of similar control groups fed on standard chick mash. Thus it appeared probable that weight gains comparable to those observed 
Table 3. Relation between the amount of supplement of Bact. coli protein and the weight gains of chicks receiving a basal diet of barley, bran and fish solubles

\begin{tabular}{|c|c|c|c|c|c|c|}
\hline Exp. no. & Diet & $\begin{array}{c}\text { Bact. coli } \\
\text { protein } \\
(\%)\end{array}$ & $\begin{array}{l}\text { No. of } \\
\text { chicks }\end{array}$ & $\begin{array}{c}\text { Duration of } \\
\text { experiment } \\
\text { (weeks) }\end{array}$ & $\begin{array}{l}\text { Mean weight } \\
\text { gain with its } \\
\text { standard error }\end{array}$ & $\begin{array}{l}\text { Mean weight } \\
\text { gain as per- } \\
\text { centage of mean } \\
\text { weight gain of } \\
\text { chicks fed on } \\
\text { standard mash }\end{array}$ \\
\hline I & $\begin{array}{l}\text { Basal } \\
\text { Basal without } \\
\text { fish solubles }\end{array}$ & $\begin{array}{l}0 \\
5\end{array}$ & $\begin{array}{l}13 \\
12\end{array}$ & $\begin{array}{l}3 \\
3\end{array}$ & $\begin{array}{r}69 \pm 5 \cdot 1 \\
122 \pm 3 \cdot 6\end{array}$ & $4^{*}$ \\
\hline 2 & Standard & - & I 1 & 3 & $157 \pm 10.7$ & 一 \\
\hline 3 & $\begin{array}{l}\text { Basal } \\
\text { Basal } \\
\text { Basal } \\
\text { Standard }\end{array}$ & $\begin{array}{l}0.5 \\
1 \\
2 \\
-\end{array}$ & $\begin{array}{l}21 \\
20 \\
20 \\
20\end{array}$ & $\begin{array}{l}3 \\
3 \\
3 \\
3\end{array}$ & $\begin{array}{r}81 \pm 4 \cdot 0 \\
88 \pm 3 \cdot x \\
113 \pm 2 \cdot 9 \\
148 \pm 9 \cdot 5\end{array}$ & $\begin{array}{l}55 \\
59 \\
76 \\
-\end{array}$ \\
\hline 4 & $\begin{array}{l}\text { Basal } \\
\text { Standard }\end{array}$ & $\underline{1}$ & $\begin{array}{l}20 \\
17\end{array}$ & $\begin{array}{l}3 \\
3\end{array}$ & $\begin{array}{r}99 \pm 3 \cdot 2 \\
162 \pm 4.4\end{array}$ & 6r \\
\hline 5 & $\begin{array}{l}\text { Basal } \\
\text { Standard }\end{array}$ & $\underline{3}$ & $\begin{array}{l}18 \\
21\end{array}$ & $\begin{array}{l}3 \\
3\end{array}$ & $\begin{array}{l}163 \pm 8 \cdot 3 \\
199 \pm 8 \cdot 7\end{array}$ & 82 \\
\hline 6 & $\begin{array}{l}\text { Basal } \\
\text { Standard }\end{array}$ & $\frac{4}{-}$ & $\begin{array}{l}20 \\
18\end{array}$ & $\begin{array}{l}3 \\
3\end{array}$ & $\begin{array}{l}172 \pm 4^{\circ} 0 \\
176 \pm 9^{\circ} 1\end{array}$ & $\frac{98}{-}$ \\
\hline
\end{tabular}

The basal diet contained $12.2 \%$ protein.

- Calculated by reference to Exp. 2 which was carried out immediately after Exp. I using chicks from the same stock, and the same brooder.

with the standard mash could not be attained with this basal diet. The results were nevertheless encouraging, since weight gains of this magnitude would not have been anticipated with a diet containing only $13 \%$ protein. In view of the indications in these results, the protein in this basal ration was increased from 7.7 to $12.5 \%$ by the addition of extracted soya-bean meal. To this was added $4 \%$ Bact. coli protein to make a diet containing $16.5 \%$ protein. One group of chicks was fed with this and another with the standard diet. The weight gains of the experimental group were significantly greater than those of the control group (Table 4). This result was confirmed by feeding three further groups of about eighteen chicks on the same Bact. coli-supplemented diet; their mean weights at 4 weeks were respectively $356,367,367 \mathrm{~g}$. The mean weights of two of the groups kept to 6 weeks were respectively 598 and 600 g. The

\section{Table 4. Weight gains of chicks fed on an adequate basal diet with a supplement} of $4 \%$ Bact. coli protein and on a standard chick mash

\begin{tabular}{|c|c|c|c|c|c|c|c|}
\hline \multirow[b]{2}{*}{ Diet } & \multirow[b]{2}{*}{ Protein } & \multirow{2}{*}{$\begin{array}{l}\text { No. of } \\
\text { chicks }\end{array}$} & \multicolumn{4}{|c|}{ Mean weight gain in week } & \multirow{2}{*}{$\begin{array}{l}\text { Mean final weigh } \\
\text { with its } \\
\text { standard error }\end{array}$} \\
\hline & & & $\mathbf{I}$ & 2 & 3 & 4 & \\
\hline $\begin{array}{l}\text { hick mash } \\
\text { with } 4 \% \text { Bact. }\end{array}$ & $\begin{array}{l}18 \cdot 3 \\
16 \cdot 5\end{array}$ & $\begin{array}{l}19 \\
16\end{array}$ & $\begin{array}{l}34 \\
38\end{array}$ & $\begin{array}{l}66 \\
85\end{array}$ & $\begin{array}{l}87 \\
97\end{array}$ & $\begin{array}{l}123 \\
125\end{array}$ & $\begin{array}{l}348 \pm 7 \cdot 2 \\
3^{8} 3 \pm 9 \cdot 0\end{array}$ \\
\hline
\end{tabular}

Standard chick mash

Basal diet with $4 \%$ Bact.

$16 \cdot 5$

I6

$383 \pm 9 \cdot 0$

The basal diet contained 10\% extracted soya-bean meal, which brought the total of vegetable protein in it to $12.2 \%$.

The mean initial weight in both groups was $38 \mathrm{~g}$. The difference of $35 \mathrm{~g}$ between the means of the weight gains over 4 weeks is significant $(t=3.215, P<0.01)$. 
mean weight at 6 weeks in the standard-mash group was $570 \mathrm{~g}$. These figures are reported to demonstrate that these chicks were on a relatively high plane of nutrition. Thus in the work of Carpenter \& Duckworth (1951) the average weight of cockerels on the control diet was $445 \mathrm{~g}$ at 6 weeks old and in that of Wilson (1953) the average weights of controls at $\mathrm{I}$ month were 222, 250 and $295 \mathrm{~g}$. In the work of Anderson, Slinger \& Pepper (1953) in Canada, the average weight of a control group of cockerels at 5 weeks was $508 \mathrm{~g}$.

Though the likely explanation of these results was that the Bact. coli was taking the place of animal proteins, there appeared to be also an alternative hypothesis, namely that it was supplying bacterial growth factors earlier, in the period before the establishment of the animal's own intestinal flora. It was of interest to know therefore whether the effect of Bact. coli continued after the first 2 weeks of life. Two groups of twenty chicks were fed for I week with the basal diet and a supplement of $5.25 \%$ Bact. coli protein. At the end of I week, the fish solubles were omitted from the basal diets of both groups, one group continued to receive the same supplement of Bact. coli and the other group received only one-half. This change had no immediate effect and at the end of the 2nd week the mean weights of the two groups were the same. The reduced supplement was again halved, so that during the $3^{\text {rd }}$ week the supplement of Bact. coli protein for this group was only $\mathrm{I} \cdot 3 \%$. During this $3^{\text {rd }}$ week this group gained less weight, and the difference in the weight gains over this week was statistically significant $(P<0.01)$. It would thus appear that a reduction of the supplement below an effective level was immediately reflected in the rate of weight gain, and that the need for the supplement was still present in the $3^{\text {rd }}$ week.

\section{Toxicity}

Evidence of innocuity was incidentally obtained in this work as follows: ( 1 ) No deaths other than accidental ones occurred in the experimental rats. (2) Of 437 chicks fed on diets containing Bact. coli protein, $4.6 \%$ died from all causes compared with $4.9 \%$ in 205 chicks fed on standard mash. These mortalities are moderate in view of the fact that weak chicks were not removed. (3) Although each batch of Bact. coli protein was in use for only a few days the rates of growth in experimental groups did not vary, as would have been expected if some batches had been toxic. (4) A group of twelve Rhode Island Red $\times$ Light Sussex cockerels was fed from 2 days old to maturity on a diet consisting of the basal mash (12.2\% protein) and $5 \cdot 25 \%$ Bact. coli protein, without access to any other edible material. The general trend of their growth rates was uninterrupted, and their individual optimum marketing weights (the last fortnightly weight record before there was a marked fall in the rate of weight gain) were as follows: $2100 \mathrm{~g}$ at $\mathrm{I} 4$ weeks (a stray breed), 2500, 2800, 2800, 2900 and $2950 \mathrm{~g}$ at $\mathrm{I} 6$ weeks, and $2700,2800,305^{\circ}, 335^{\circ}, 355^{\circ}$ and $365^{\circ} \mathrm{g}$ at $\mathrm{I} 8$ weeks.

It should be noted that the suspensions used were always proved to be sterile by cultural examination. The giving of suspensions containing living organisms caused retardation of growth, and in very young animals $5-10 \%$ mortality from Bact. coli bacteraemia. 


\section{DISCUSSION}

The leading issue in this work was whether the supplementary proteins customarily incorporated in animal foods could be replaced by some preparation of Bact. coli. This possibility was demonstrated, but the result was not in itself unexpected since the present conception of ruminant digestion is that the bacteria and protozoa of the rumen provide the animal with proteins and associated vitamins and that these can be synthesized, even from inorganic nitrogen (Wegner, Booth, Bohstedt \& Hart, 1940). The observation assumes importance, however, when considered in conjunction with the other results, namely that the amount of protein required was small, that only one microbial species was used, that the bacterial suspension was innocuous, and that large-scale preparation with simple medium was feasible.

There appears to be no reason to doubt that a high rate of weight gain in relation to the amount of total protein and of bacterial protein was a feature of these results. Thus, chicks fed on diets containing only r. $33 \%$ protein as Bact. coli and fish solubles and only $13.5 \%$ total protein thrived, and chicks receiving supplements of $4.33 \%$ Bact. coli and fish solubles proteins gained more weight than controls receiving $12.5 \%$ animal-protein supplements, equivalent probably to $9 \%$ animal protein.

Having in mind the diversity of microbial species that take part in ruminant digestion and the apparently beneficial part played in it by protozoa (McNaught, Owen, Henry \& Kon, 1954), it was surprising to find that such a marked effect could be exerted upon the nutritive value of a diet by one microbial species.

The most unexpected feature of these results was the observation that, whereas killed whole liquid culture was toxic, separated organisms were not. As stated earlier, it was the hope that bacterial protein separated from its polysaccharide would be innocuous that made the idea of feeding Bact. coli appear feasible. It had not been expected that the polysaccharide could be used. The somatic antigen, polysaccharide or endotoxin of Bact. coli is toxic for guinea-pigs by parenteral injection in doses of about $3 \mathrm{mg} / \mathrm{kg}$ (Roberts, 1949). There is not, as far as is known, any detailed information on the toxicity per os of polysaccharide from coliform organisms, but, as the toxicity of these organisms is exerted by the polysaccharide, and as it is commonly assumed that some members of the coliform group, including Bact.coli, cause disease within the intestine, some ill effects might well have been expected to follow the continuous feeding of massive quantities of polysaccharide. This innocuity of whole cells was gratifying as there may have been advantages in leaving the polysaccharide in the preparation; it may have carried some activity and, in fact, is likely to have carried the antibiotic activity of Bact. coli (Heatley \& Florey, 1946); its removal would involve a loss of energy-yielding material; in large-scale manufacture it is likely to be more convenient to retain it than to discard it.

The use of Bact. coli in nutrition would not be feasible either experimentally or commercially if it were not for its capacity to grow profusely by aeration in submerged culture in chemical media. The experience gained in this investigation in the routine preparation of bacterial protein demonstrated the practicability and reproducibility of the method of preparation and the uniformity of its nutritive properties from batch to batch. 
The known properties of Bact. coli and the observations reported here show that it is a promising food organism; its advantages may be summarized as follows: (I) innocuity of killed organisms, (2) growth from inorganic nitrogen compounds, (3) synthesis of B-vitamins, (4) existence of strains that respond to the growth-promoting effect of aeration, (5) use of, or easy adaption to the use of, a cheap carbohydrate substrate, (6) innocuity during growth, (7) no sporulation, and low resistance to heat.

The results reported here support the recent work of Anderson, Slinger \& Pepper (1953), Anderson, Slinger, Pepper \& Hauser (1953) and Romoser, Shorb \& Combs (1953), who showed that small but significant increases in weight gains of chicks and poults occurred when both living Bact. coli cultures and antibiotics were added to their diets. Their results suggested that the nutritional effects of antibiotics were due to suppression of vitamin-consuming organisms and encouragement of vitamin producers. There are some grounds therefore for suspecting that the high rates of weight gains in relation to the total nitrogen in the diet observed here and in the practice of antibiotics feeding, may be common manifestations of the nutritional value of bacterial protein.

\section{SUMMARY}

I. Cultures of Bact. coli in a chemical medium were centrifuged, and the cells killed by heating at $80^{\circ}$ for $\mathrm{I} h$. The killed cells were mixed with cereals and fed to rats and chicks. Comparable groups received cereals and fish meal or standard diets. The animals were observed for 3 or 4 weeks and weighed each week.

2. Bact. coli was qualitatively equal to fish meal as a protein supplement for young rats. The optimum supplement in a diet of good barley meal and bran was of the order of $\mathrm{r}-2 \%$.

3. In chick diets Bact. coli with I $\%$ fish solubles replaced the fish meal and the factors normally supplied to chicks as milk, liver meal and yeast.

4. The innocuity of the suspension of Bact. coli was shown in experiments with more than 600 animals fed with it. Alternative preparations containing culture fluid were demonstrably toxic.

5. The ability of Bact. coli protein to promote growth appeared to be greater than that of the conventional animal proteins; it is suggested that this and the beneficial effects of antibiotics feeding may be related phenomena.

6. These findings and other known properties of Bact. coli suggest that it may be used as a food organism.

I am indebted to Dr D. Riding for the facilities to carry out these researches; to Mr C. A. Macdonald for carrying out the chemical analyses, to Mr R. A. Taggart for the statistical work, to Mr G. E. Shaw for day-to-day advice on biochemical matters, and to Miss J. A. F. Townshend and Miss M. Lever for technical assistance.

\section{REFERENCES}

Anderson, G. W., Slinger, S. J. \& Pepper, W. F. (1953). F. Nutr. 50, 35

Anderson, G. W., Slinger, S. J., Pepper, W. F. \& Hauser, M. M. (1953). F. Nutr. 50, 47.

Bruce, H. M. \& Parkes, A. S. (1949). F. Hyg., Camb., 47, 202.

Carpenter, K. J. \& Duckworth, J. (1951). $\mathscr{Y}$. agric. Sci. 41, 297. 
Chain, E. B., Paladino, S., Callow, D. S., Ugolini, F. \& van der Sluis, J. (1952). In First International Symposium on Chemical Microbiology, p. 73. Monogr. Ser. Wld Hlth Org. no. ro. Geneva: World Health Organization.

Heatley, N. G. \& Florey, H. W. (1946). Brit. 7. exp. Path. 27, 378.

McNaught, M. L., Owen, E. C., Henry, K. M. \& Kon, S. K. (1954). Biochem. F. 56, 151.

Roberts, R. S. (1949). F. comp. Path. 59, 284.

Roberts, R. S. (1950). Nature, Lond., 165, 494.

Romoser, G. L., Shorb, M. S. \& Combs, G. F. (1953). Proc. Soc. exp. Biol., N.Y., 83, 7.

Wegner, M. I., Booth, A. N., Bohstedt, G. \& Hart, E. B. (1940). F. Dairy Sci. 23 , I 123.

Wilson, J. E. (1953). Vet. Rec. 65, 633.

Woodman, H. E. \& Evans, R. E. (195I). Y. agric. Sci. 41, 102.

\title{
Hydrocephalus in Young Rabbits Associated with Maternal Vitamin A Deficiency
}

\author{
By G. E. LAMMING* \\ A.R.C. Unit of Animal Reproduction, Huntingdon Road, Cambridge \\ AND D. H. M. WOOLLAM AND J. W. MILLEN \\ Department of Anatomy, University of Cambridge
}

(Received 3 May 1954)

After earlier studies on the effect of incipient vitamin A deficiency on reproduction in the female rabbit (Lamming, Salisbury, Hays \& Kendall, $1954 a, b$ ) the present studies were undertaken to determine the effect of incipient vitamin A deficiency in the dam on development and growth of the young.

Many published accounts have appeared of the effect of vitamin A deficiency on farm and laboratory animals during the period of growth (in pigs, Hart, Miller \& McCollum, 1916; Hughes, Lienhardt \& Aubel, 1929-30; Dunlop, 1934; Hostetler, Foster \& Halverson, 1935; Kellermann, Schulz \& Thomas, r943; in cattle, Hart, Steenbock, Humphrey \& Hulce, 1924-5; Moore, Huffman \& Duncan, 1935; Moore \& Sykes, I94I; in sheep, Eveleth, Bolin \& Goldsby, I949; in rabbits, Phillips \& Bohstedt, I938).

In most accounts convulsion, paralysis and incoordination have been noted as signs. Already 30 years ago Hart et al. (1924-5) reported that calves from cows with vitamin A deficiency were often born dead or died soon after birth. Later Moore et al. (1935) described blindness, xerophthalmia and partial paralysis in calves born from vitamin A-deficient cows, as well as in calves receiving poor-quality roughage from the age of 3 months.

The cause of these signs has been much debated. After examination of vitamin Adeficient calves Moore et al. (1935) concluded that the blindness was due to injury of the optic nerve at the optic foramina, presumably owing to pressure by the surrounding bone, although they were reluctant to accept the view that vitamin A deficiency as

- Present address: University of Nottingham, School of Agriculture, Sutton Bonington, Loughborough. 